\author{
M.M. Berest ${ }^{1}$, O.P. Koiuda ${ }^{2}$, H.G. Sobolieva ${ }^{2}$ \\ ${ }^{1}$ Simon Kuznets Kharkov National University of Economics, Ukraine \\ ${ }^{2}$ O.M. Beketov National University of Urban Economy in Kharkiv, Ukraine
}

\title{
FORMATION OF INDICATORS SYSTEM FOR DIAGNOSING THE DEVELOPMENT OF CRISIS PHENOMENA IN THE ACTIVITIES OF AN ENTERPRISE
}

\begin{abstract}
Approaches to identifying gradations of crisis development at an enterprise are generalized. A comparative analysis of the coefficient composition of methods for assessing the likelihood of bankruptcy of enterprises, developed by foreign and Ukrainian scientists. The key analytical directions of diagnostics are highlighted, the economic content of the indicators used is disclosed. A refined complex of financial coefficients is proposed for assessing crisis phenomena in the activities of an enterprise.
\end{abstract}

Keywords: diagnostics of crisis phenomena, assessment of bankruptcy probability, financial indicators.

\section{Formulation of the problem}

The current stage of the functioning of the Ukrainian economy is characterized by the presence and development of sufficiently deep crisis phenomena, which leads to a decrease in the efficiency of the functioning of business entities, deterioration in their financial condition, leads to the emergence of a large number of unprofitable enterprises and bankrupt enterprises. So, according to the State Statistics Service of Ukraine, the share of unprofitable enterprises over the past 5 years has been stable at about $27 \%$, and the volume of losses they received in 2019 alone amounted to UAH 248,240.6 million [1].

The development of the identified trends requires widespread introduction of analytical processes into the practice of financial management of enterprises, the purpose of which is to diagnose crisis phenomena. This is due to the fact that an adequate response of the enterprise management bodies to a crisis situation is possible only on the basis of timely identification and adequate diagnosis of the symptoms and causes of the crisis.

\section{Analysis of previous research and publications}

The problems of a comprehensive assessment of the emergence and depth of crisis phenomena in the activities of business entities are considered in the works of both Ukrainian and foreign scientists, in particular, O.A.

Among the most well-known and frequently used methods for assessing the likelihood of bankruptcy, developed by foreign scientists, one should single out the two-factor and five-factor models of E. Altman (USA), the nine-factor model of J. Fulmer (France), the four-factor model of R. Lis (Great Britain), the five- factor model of J. Conan and M. Golder (France), the four-factor model of R. Tuffler and G. Tishaw (Great Britain), the three-factor model of J. Lego (Canada), the four-factor model of G. Springgate (Canada), the system of indicators of W. Beaver (USA), etc. Among the developments of Ukrainian scientists, one can single out the discriminant models of O.A. Tereshchenko, model for assessing the probability of bankruptcy A.V. Matveychuk, models for calculating the integral indicator of financial condition for assessing the probability of a debtor's default, recommended by the National Bank of Ukraine (NBU), etc.

At the same time, an analysis of the literature and existing methodological developments for diagnosing the financial condition and, in particular, assessing the manifestations of the crisis at enterprises showed that at present there is no unified approach to the formation of a set of indicators with the help of which the assessment and diagnosis of the presence and depth of manifestations of crisis phenomena in the activities of the enterprise.

\section{Forming the purpose of the article}

The aim of the study is to generalize methodological approaches and develop recommendations for the formation of a system of indicators for diagnosing the development of crisis phenomena in the activities of an enterprise.

\section{Presentation of the main material}

Let us analyze the literary sources in which the problem of assessing the crisis state of enterprises is considered.

So, Blank I.A. [2] identified three gradations of the development of the crisis at the enterprise: a light 
financial crisis, a deep financial crisis and a financial catastrophe.

To assess the level of the crisis, the scientist proposed using indicators of liquidity, market value, financial stability, formation of financial resources and cost dynamics.

The authors of [3] considered three phases of the crisis - in the first phase, income from core activities decreases, in the second phase, a loss is formed, liquidity decreases and there is a shortage of own working capital, the third phase is characterized by a significant increase in borrowed capital and an imbalance in receivables and payables in addition. As the main indicators of the crisis development of the enterprise, scientists identified the indicators of the efficiency of the enterprise, liquidity, financial stability and business activity.

O.G. Melnik [4] identified 6 states of an enterprise - ideal, favorable, destabilization, pre-crisis, crisis and catastrophic, which ultimately manifests itself through insolvency, violation of the capital structure, absence or low level of financial performance, low level of economic activity or its absence.

O. A. Tereshchenko [5] has formed the following approach to assess the development of crisis phenomena:

a phase that does not threaten the operation of the enterprise, possible deviations in the indicators of solvency and financial stability may indicate the presence of crisis phenomena;

a phase that threatens the existence of the enterprise, therefore the enterprise needs a financial reorganization. According to the scientist, the entry of an enterprise into this phase of the crisis can be detected through a drop in sales volumes, a decrease in current liquidity and autonomy ratios, a deterioration in business activity, a decrease in financial performance or its absence; deterioration in the ratio of operating and investment cash flows to assets and operating cash flow to the amount of net income;

crisis state leading to the liquidation of the enterprise. The main features of this phase are unprofitability and insolvency of the enterprise; persistent negative trends in the dynamics of financial independence and business activity, a significant deterioration in the value of the ratio of operating and investment cash flows to assets and operating cash flow to the amount of net income.

A. V. Cherep and A. I. Pavlenko [6] proposed to identify the areas of prevention, prevention and recovery from the crisis for the enterprise, and then apply a different combination of strategic and tactical approaches to anti-crisis management for different areas.In the course of the study, the authors formed such groups of indicators for assessing the crisis as liquidity, financial stability, business activity and quality of management. E. Golovach identifies similar groups of indicators influencing the development of crisis phenomena in agricultural enterprises [7]. At the same time, according to the results of processing the opinions of experts, the development of the crisis is strongly influenced by indicators of financial stability, the average level of influence is demonstrated by indicators of liquidity and quality of management, and indicators of business activity indirectly affect [7, p. 113].

In the study by O. O. Melnichenko [8], a method is proposed for assessing the crisis state of an enterprise, which takes into account the allocation of elements of the economic system of an enterprise for individual business processes corresponding to the stages of the operating cycle in which the crisis originated, and thanks to this, it allows to determine the degree of depth of crisis phenomena on enterprise.The result of using the proposed technique is the formation of an integral indicator for assessing the crisis state of the enterprise. This approach, according to the author, makes it possible to identify signs of crisis phenomena in the early stages before they have time to affect the financial performance of the enterprise.

Generalization of the selected approaches allows us to conclude that the diagnosis of the crisis state of an enterprise is complex and involves the use of different analytical directions.In this regard, it is advisable to review and analyze existing approaches to the formation of a set of indicators proposed by the authors for diagnosing the financial condition of enterprises in order to identify negative trends in their work or signs of a crisis.

Thus, let us conduct a comparative analysis of the coefficient composition of methods for assessing the probability of bankruptcy of enterprises, developed by foreign scientists (Table. 1) (compiled by the authors, according to [9]).

Let us analyze the data presented in table 1. So, among the coefficients with which the authors of the methods propose to assess the level of development of the crisis at the enterprise and the likelihood of its bankruptcy, most often (namely, in 8 out of 9 considered methods) indicators of the capital structure (financial stability) are used - coefficients that characterize the ratio between sources financial resources of the enterprise.

In our opinion, this is due to the specifics of the influence of various sources of financial resources on the financial condition of an economic entity. Thus, an increase in the share of assets formed at the expense of equity capital and, in particular, retained earnings, indicates an increase in the financial independence of the enterprise from creditors and other external sources, which strengthens the financial condition of the company and prevents the development of the crisis. In this group of indicators, the authors also used the ratio 
of equity and debt capital (E. Altman, R. Lis), the indicator of financial leverage (W. Beaver), the ratio of equity capital to enterprise assets (J. Lego), the share of formation of assets due to short-term.

Table 1

Comparative analysis of the coefficient composition of foreign methods for assessing the likelihood of bankruptcy of enterprises

\begin{tabular}{|c|c|c|c|c|c|c|c|c|}
\hline № & $\begin{array}{l}\text { Methodology / Groups of } \\
\text { indicators }\end{array}$ & 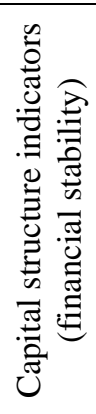 & 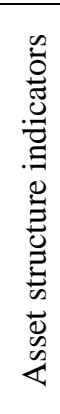 & 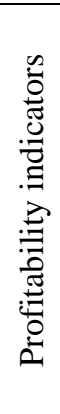 & 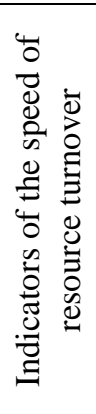 & 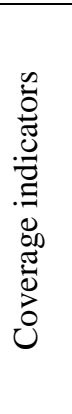 & 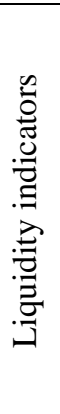 & 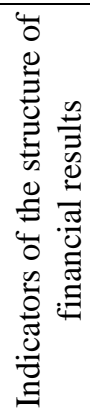 \\
\hline 1 & $\begin{array}{l}\text { Two-factor model by } \\
\text { E. Altman (USA) }\end{array}$ & + & - & - & - & - & + & - \\
\hline 2 & $\begin{array}{l}\text { Five-factor model by } \\
\text { E.Altman(USA) }\end{array}$ & + & + & + & + & - & - & - \\
\hline 3 & $\begin{array}{l}\text { Nine-factor model by } \\
\text { J.Fulmer(France) }\end{array}$ & + & + & + & + & + & + & - \\
\hline 4 & $\begin{array}{l}\text { Four-factor model by R. Fox } \\
\text { (Great Britain) }\end{array}$ & + & + & + & - & - & - & - \\
\hline 5 & $\begin{array}{l}\text { Five-factor model of J. Conan } \\
\text { and M. Golder (France) }\end{array}$ & + & + & - & - & + & - & + \\
\hline 6 & $\begin{array}{c}\text { Four-factor model by R. } \\
\text { Tuffler and G. Tishaw } \\
\text { (Great Britain) }\end{array}$ & + & - & - & + & + & + & - \\
\hline 7 & $\begin{array}{l}\text { Three-factor model by } \mathrm{J} . \\
\text { Lego (Canada) }\end{array}$ & + & - & + & + & - & - & - \\
\hline 8 & $\begin{array}{c}\text { Four-factor model by G. } \\
\text { Springgate (Canada) }\end{array}$ & - & + & + & + & + & - & - \\
\hline 9 & $\begin{array}{c}\text { Scorecard by } \\
\text { W. Beaver (USA) }\end{array}$ & + & + & + & - & + & + & - \\
\hline & $\begin{array}{l}\text { Frequency of using group } \\
\text { indicators in methods }\end{array}$ & 8 & 6 & 6 & 5 & 5 & 4 & 1 \\
\hline
\end{tabular}

In second place in terms of frequency of use by the authors are analytical indicators characterizing the structure of the assets of the enterprise and the profitability of its activities. Let us consider separately these directions of diagnostics from the point of view of assessing the development of crisis phenomena at the enterprise.

So, among the coefficients for assessing the structure of assets, the authors most often use the indicator of the share of net working (working) capital in assets (E. Altman, R. Lees, G. Springgate, W. Beaver). Net working capital is calculated as the difference between current assets and current liabilities and shows how much of current assets is financed from long-term sources of funding (equity and long-term liabilities).Accordingly, the drop in the share of net working capital in assets indicates a decrease in the level of financial stability. the deterioration of the financial condition of the enterprise and the growth of its dependence on short-term borrowed capital, which determines the advisability of using this indicator in the course of diagnosing the development of the crisis at the enterprise. Also, the authors of the methods proposed the use of such indicators for assessing the structure of assets:

The share of quick assets in the total amount of assets (J. Conan and M. Golder) - affects the increase or decrease in the level of liquidity of assets;

The share of tangible non-current assets in the total value of assets (J. Fulmer) - characterizes the share of the production potential of the enterprise in the overall structure of assets.

Profitability indicators are the most important indicators for assessing the development of crisis phenomena in an enterprise, since they reflect its ability to generate profit per unit of resources used. Among 6 methods, in which profitability ratios are presented, 5 authors use the return on assets indicator - the ratio of net profit (or profit before interest and taxes) to the total value of an enterprise's assets. This indicator reflects the 
overall level of efficiency of the company and the use of its assets. The growth in the level of return on assets indicates not only an increase in profitability, but also of the company's ability to increase the degree of financial stability and security due to a potential increase in the share of profit in the structure of funding sources. In addition, it is profit that is the main internal source of financial development of an economic entity, the formation of its reserves.All this emphasizes the importance and expediency of using profitability indicators in the course of diagnosing crisis phenomena in the activities of an enterprise. It also should be noted that in the nine-factor model of J. Fulmer, unlike the others, the return on equity indicator is used, calculated based on profit before tax - it characterizes the level of efficiency in the use of equity capital and is of interest primarily to the owners of the enterprise, which somewhat reduces the feasibility of its use in the context of the topic of this research.

Further, according to the frequency of use, the authors should highlight the turnover indicators, which characterize the turnover rate of the enterprise resources. The only representative of this analytical direction in the considered methods is the asset turnover ratio, which reflects the ratio of sales proceeds and the total value of the company's assets. The use of this indicator in the course of diagnosing the development of crisis phenomena at an enterprise is due to the fact that it makes it possible to assess the intensity of the use of resources belonging to the enterprise involved in its activities.The higher the value of the turnover ratio, the more income each monetary unit of asset value generates. However, it should be noted that the value of the indicator is largely determined by the industry in which the enterprise operates, and this should be taken into account in the process of diagnosing the development of crisis phenomena.

Indicators of coverage of obligations are used by the authors in 5 methods out of 8 considered and characterize the ability of an enterprise to fulfill its obligations from various sources. So, the authors propose to use the following coefficients:

Coverage ratio by changes in the balance of accounts payable (J. Fulmer);

The ratio of coverage of borrowed capital at the expense of profit before interest and taxes (J. Conan and M. Golder);

The ratio of coverage of short-term liabilities at the expense of profit from sales (G. Springgate, R. Tuffler and G. Tishaw);

Beaver's ratio - the ratio of net cash flow to borrowed capital (W. Beaver).

We see that the main sources of payments in this aspect are either profit before interest and taxes, or cash flow. The importance of using these indicators in the course of diagnosing the development of crisis phenomena lies precisely in the fact that they characterize one of the aspects of the company's solvency.

Another aspect of solvency reflects liquidity indicators, which allow us to assess the ability of an enterprise to fulfill its obligations through mobile assets. For this, the authors suggest using the following coefficients:

Current liquidity ratio (coverage) (E. Altman, J. Fulmer, W. Beaver) - the ratio of current assets and current liabilities, characterizes the company's ability to repay short-term liabilities;

The ratio of current assets and liabilities (R. Taffler and G. Tishaw) - shows the ability to meet the total liabilities of the enterprise at the expense of mobile assets.

In our opinion, the assessment of the company's solvency, regardless of the selected sources of repayment of obligations, is of paramount importance for identifying signs of a crisis at the enterprise, since solvency is one of the parameters by which creditors have the right to go to court to initiate a bankruptcy case of the debtor.

It should be noted that in the five-factor model of J. Conan and M. Golder, in contrast to all others, the use of coefficients characterizing the structure of costs is proposed, namely, the share of financial costs in revenue and the share of personnel costs in added value after tax. These coefficients, therefore, are not among the main indicators reflecting the development of crisis phenomena at the enterprise, but can be used as part of additional, deeper analytical studies.

Among the developments of domestic authors, attention should be paid to the model for assessing the axiological (subjective) probability of bankruptcy of Ukrainian enterprises in the form of a discriminant function, developed by A. V. Matveychuk [10]. It includes the following indicators:

The asset mobility ratio reflects the ratio of current and non-current assets, i.e. characterizes the structure of assets in terms of their mobility;

The turnover ratios of accounts payable and equity capital - characterize the intensity of the use of these sources of financing;

Return on assets - calculated as the ratio of total assets to sales revenue. That is, in fact, this is the inverse indicator of the asset turnover ratio, it characterizes the rate of asset turnover and the intensity of their use;

The ratio of provision with own circulating assets in general, determines the structure of circulating assets from the point of view of ensuring the financial independence of the enterprise;

the ratios of concentration of borrowed funds and coverage of liabilities by equity capital - characterize 
the structure of sources of financing for an enterprise in the context of maintaining its financial stability.

It can be seen that this list does not include the coefficients of profitability and solvency, which allows us to conclude that this model is rather narrow.

The NBU Regulations on Determining the Level of Credit Risk for Active Banking Operations [11], which developed an approach to assessing the probability of default of a borrower enterprise, uses coefficients characterizing the financial condition of the borrower in the following areas:

1) indicators characterizing the solvency of the enterprise through the liquidity of its assets: the coefficient that determines the ability of the enterprise to quickly meet the need for liquid funds, and the indicator of the enterprise's ability to cover short-term liabilities at the expense of current assets;

2) Indicators that determine the rate of turnover of assets of the enterprise, as well as the rate of repayment of accounts payable and receivable;

3) Indicators characterizing the ability of the enterprise to cover its debts at the expense of income from the main activity; at the expense of equity capital or at the expense of profit from operating activities;

4) Indicators of profitability (ability to generate a positive financial result): the coefficient of efficiency of using the assets of the enterprise; indicator of ability to finance non-operating expenses based on operating results; an indicator showing the share of operating profit before depreciation in the total sales of products;

5) Indicators of the structure of assets and capital of the enterprise: coefficients that determine, respectively, the share of own funds, the share of own current assets and the share of assets that are not directly related to operating activities in the company's balance sheet.

Thus, the approach presented in this Regulation to assessing the probability of a borrower's default is comprehensive and is focused primarily on assessing the company's ability to generate sufficient income to cover debts, ensure a liquid structure of assets and the required share of equity capital.

Ukrainian scientist O.A. Tereshchenko has developed a complex of discriminant models for assessing the probability of bankruptcy for enterprises in different industries [5]. The list of financial indicators used to build models includes the following groups:

1) Profitability ratios, calculated by profit profitability of sales and return on equity;

2) Profitability ratios calculated by cash flows return on assets and profitability of operating activities;

3) The coefficients of turnover, capital, debt capital and current assets;

4) Current liquidity ratio (coverage);
5) The coefficient of financial independence, reflecting the share of equity capital in the total volume of funding sources.

We see that the author paid the main attention in the process of analyzing crisis phenomena and the likelihood of bankruptcy to the use of coefficients that characterize the efficiency of the use of enterprise resources in various aspects - through the speed of their turnover, the level of coverage by profit or net cash flow.

Thus, the analysis made it possible to identify the main groups of financial indicators in analytical areas.

In this regard, based on the results of a comparative analysis of the coefficient composition of domestic and Ukrainian methods, for a comprehensive assessment of the development of crisis phenomena in the activities of enterprises, it is proposed to form a list of recommended indicators in accordance with the directions highlighted above. The requirements for such a list are as follows [12]:

It should include indicators that make it possible to comprehensively and reasonably assess the presence of crisis phenomena;

The number of indicators should be optimal - that is, not too small, so as not to lose sight of important aspects of the financial condition, in which manifestations of the crisis may arise, and also not too large, so as not to complicate the analysis process and not overestimate the complexity of this methodological approach;

Indicators should minimize duplication of each other, but on the contrary, complement;

Indicators should be quantitatively measurable and accessible to the analyst.

Thus, it is proposed to highlight the following indicators for the corresponding key areas of analysis:

1) to assess the capital structure (financial stability - the coefficient of financial independence as an indicator of the company's ability to cover part of its assets with its own funds;

2) to assess the structure of assets - the ratio of the net working capital to the total value of the assets of the enterprise. This indicator has a high frequency of use in the models of foreign authors and allows you to assess the degree of financial independence of an enterprise from external sources of financing;

3) to assess profitability - the profitability ratio of assets, reflecting the overall efficiency of their use. In addition, in our opinion, it is advisable to supplement it with an operating profitability ratio calculated on the basis of cash flow. This will expand the analyst's ability to identify weaknesses and more clearly identify the manifestations of the crisis in the enterprise. The negative dynamics of these ratios is a sign of low financial performance and can lead to a deepening crisis in the activities of an economic entity; 
4) to assess the rate of turnover of enterprise resources - the asset turnover ratio. This indicator reflects the level of efficiency and return on the use of assets, and is used in almost all of the above methods, which confirms the need and appropriateness of its use in the course of diagnosing crisis phenomena;

$5)$ to assess the ability of an enterprise to cover its debts at the expense of income from the main type of activity - the ratio of coverage of borrowed capital at the expense of profit before interest and taxes;

6) to assess the level of liquidity of the enterprise the coverage ratio (current liquidity), which allows you to assess the degree of solvency of the enterprise due to the liquidity of its assets. Thus, the use of the two previous coefficients at the same time will make it possible to comprehensively assess the level of the company's solvency as a whole.

\section{Conclusions and prospects for further research}

Thus, the formed set of financial indicators can be used in a complex to assess crisis phenomena in the activities of an enterprise, to identify the depth and degree of development of the crisis, and also to identify problem areas. In addition, the proposed complex of coefficients can be used to construct an integral (taxonomic) indicator of the level of crisis at an enterprise, as well as form a basis for the application of other economic and mathematical methods in the course of diagnosing crisis phenomena.

Improvement of methods and tools of analysis allows to ensure timely detection and identification of the signs of a crisis at the enterprise, which is the basis for the application of mechanisms to prevent further development or neutralize negative consequences.

Further research should be directed to the formation of a system of criteria for assessing the results of diagnostics, accurate and clear definition of the stage of development of the crisis at the enterprise which will allow the development of adequate and effective anticrisis measures.

\section{References}

$\begin{array}{cccc}\text { 1. State Statistics } & \text { Service of Ukraine. } \\ \text { URL:http:www.ukrstat.gov.ua } & & & \end{array}$

2. Blank, I.A (2006). Antikrizisnoe finansovoe upravlenie predpriyatiem / I.A. Blank- Kiev :El'ga, NikaCentr, $672 \mathrm{p}$.

3. Kopilyuk O.I., Shtangret A.M., Finansova sanaciya ta bankrutstvo pidpriemstv, Kï̈v, Ukraïna: Centr navchal'noï literaturi, 2005

4. Mel'nik O.G. Sistemi diagnostiki diyal'nosti mashinobudivnih pidpriemstv: polikriterial'na koncepciya ta instrumentarij, L'viv, Ukraïna: Vidavnictvo Nacional'nogo universitetu «L'vivs'ka politekhnika», 2010.

5. Tereshchenko O.O. Antikrizove finansove upravlinnyana pidpriemstvom : monografiya / O.O.
Tereshchenko. - 2-ge vid., bez zmin. - Kiïv : KNEU, 2006. $268 \mathrm{p}$.

6. Cherep A.V. Formuvannya strategii antikrizovogo upravlinnya pidpriemstvami mashinobuduvannya Zaporiz'koï oblasti / A.V. Cherep, A.I. Pavlenko // Visnik social'noekonomichnih doslidzhen'. - 2018. - № 1 (65). - p. 161-173.

7. Golovach K.S. Formuvannya mekhanizmu antikrizovogo upravlinnya u sil's'kogospodars'kih pidpriemstvah: dis. Na zdobuttya nauk. Stupenya kand. ekon. nauk : 08.00.04 / K.S. Golovach; Zhitomirs'kij nacional'nij agroekologichnij universitet. - Zhitomir, 2016. - 204 p.

8. Mel'nichenko O.O. Ocinka krizovogo stanu pidpriemstva / O.O. Mel'nichenko. // Visnik nacional'nogo universitetu «L'vivs'ka politekhnika»: Zbirnik naukovih prac'. - 2016. - № 851, Seriya : Menedzhment ta pidpriemnictvo Ukraïni: etapi stanovlennya i problemi rozvitku. -P. 62-68.

9. Metody ocenki veroyatnosti bankrotstva predpriyatiya : ucheb. posobie / I.I. Mazurova, N.P. Belozerova, T.M. Leonova, M.M. Podshivalova. - SPb. : Izd-vo SPbGUEF, 2012. $-53 \mathrm{p}$.

10. Matvijchuk A.V. Modelyuvannya finansovoï stijkosti pidpriemstv iz zastosuvannyam teorij nechitkoï logiki, nejronnihmerezh i diskriminantnogo analizu / A. V. Matvijchuk // Visnik NAN Ukraïni. - 2010. - № 9. - P. 2446.

11. Pro zatverdzhennya Polozhennya pro viznachennya bankami Ukraïni rozmiru kreditnogo riziku za aktivnimi bankivs'kimi operaciyami : Postanova Nacional'nogo banku Ukraïni vid 30.06.2016 r. № 351 (zizminami, vnesenimi, zgidno $\mathrm{z}$ Postanovoyu NBU vid 16.01.2017 № 5). URL:http://zakon3.rada.gov.ua/laws/show/ v0351500-16

12. Berest M.M. Formuvannya sistemi pokaznikiv monitoringu rozvitku krizovihyavishchna pidpriymstvi / M.M. Berest // Visnik ekonomiki transport i promislovosti. - 2014. Vip. $45 . \quad-\quad$ S. $54-59 . \quad$ URL: http://nbuv.gov.ua/UJRN/Vetp_2014_45_12

Reviewer: Doctor of Economic Sciences, Professor of the Department A.E. Achkasov, O.M. Beketov National University of Urban Economy in Kharkiv, Ukraine

Author: BEREST Maryna Mikolaivna

Candidate of Economic Sciences, PhD Associate Professor of the Department

Simon Kuznets Kharkov National University of Economics

E-mail-maryna.berest@hneu.net

ID ORCID: https://orcid.org/0000-0002-2410-3210

Author: KOIUDA Oleksandr Pavlovich

Candidate of Economic Sciences, PhD Associate

Professor of the Department

O.M. Beketov National University of Urban Economy in

Kharkiv

E-mail-ak1261698@gmail.com

ID ORCID: https://orcid.org/0000-0002-4205-8900

Author: SOBOLIEVA Hanna Grigoriivna

Candidate of Economic Sciences, PhD Associate

Professor of the Department

O.M. Beketov National University of Urban Economy in Kharkiv

E-mail-soboliva.ag@gmail.com 


\section{ФОРМУВАННЯ СИСТЕМИ ПОКАЗНИКІВ ДІАГНОСТИКИ РОЗВИТКУ КРИЗОВИХ ЯВИЩ В ДІЯЛЬНОСТІ ПІДПРИСМСТВА}

М.М. Берест ${ }^{1}$ О.П. Коюда ${ }^{2}$, Г.Г. Соболєва ${ }^{2}$

${ }^{1}$ Харківський національний економічний університет імені Семена Кузнеця, Україна

${ }^{2}$ Харківський національний університет міського господарства імені О.М. Бекетова, Україна

В роботі проведено аналіз літературних джерел $i$ узагальнено підходи до виділення та характеристики градацій розвитку кризи на підприємстві. Встановлено, щзо діагностика кризового стану підприємства носить комплексний характер і передбачає використання різних аналітичних напрямків. Проведено порівняльний аналіз коефічієнтного складу методик оцінки ймовірності банкрутства підприємств, розроблених зарубіжними вченими. Виділено ключові групи використовуваних показників, серед яких коефіціснти фінансової стійкості, структури активів, рентабельності, швидкості обороту ресурсів, покриття зобов'язань, ліквідності і структури фінансових результатів. Визначено частоту використання показників за різними аналітичними напрямками в методиках, щяо порівнюються, проранжовано групи показників по даному параметру. Встановлено, щзо найбільш часто автори використовували для оцінки глибини кризи показники структури капіталу (фінансової стійкості), а найменш часто - показники структури фінансових результатів.

Проведено аналіз підходів до оцінки ймовірності дефолту підприємства, пропонованих украӥнськими вченими. Порівняльний аналіз коефіцієнтного складу вітчизняних методик показав, щзо автори приділяють увагу різним аналітичним напрямкам, зокрема, концентруються на оцінці здатності підприємства генерувати достатній обсяг доходів для покриття боргів, забезпечення ліквідної структури активів $i$ необхідної частки власного капіталу, а також виділяють коефіцієнти, які характеризують ефективність використання ресурсів підприємства в різних аспектах - через швидкість їх обороту, рівень покриття прибутком або чистим грошовим потоком.

На основі проведених досліджень для здійснення комплексної оцінки розвитку кризових явищ в діяльності підприсмств в статті сформовано перелік рекомендованих показників, виділені $і$ розкриті вимоги до них. Показники згруповані за ключовими напрямами аналізу, розкрито їх економічний зміст. Сформований набір фінансових показників може в комплексі використовуватися для оцінки кризових явищ в діяльності підприємства, виявлення глибини і ступеня розвитку кризи, а також виявлення проблемних сфер.

Ключові слова: діагностика кризових явищ, оцінка ймовірності банкрутства, фінансові показники. 